\title{
UPAYA MENINGKATKAN AKTIVITAS DAN HASIL BELAJAR SISWA DENGAN MENERAPKAN MODEL PEMBELAJARAN SNOWBALL TROWING PADA MATERI SEGITIGA DAN SEGIEMPAT
}

\author{
${ }^{1}$ Refo Pramono, ${ }^{2}$ Dewi Herawaty, ${ }^{3}$ M.Fachruddin S \\ ${ }^{1,2,3}$ Program Studi Pendidikan Matematika JPMIPA FKIP Universitas Bengkulu \\ e-mail : ${ }^{1}$ refopramono427@gmail.com, ${ }^{2}$ dewiherawaty71@gmail.com, ${ }^{3}$ m.fachruddin.s@gmail.com
}

\begin{abstract}
Abstrak
Penelitian ini bertujuan untuk meningkatkan aktivitas dan hasil belajar siswa dengan menerapkan model pembelajaran Snowball Throwing. Jenis penelitian yang dilaksanakan adalah Penelitian Tindakan Kelas (PTK) dengan teknik pengumpulan data melalui lembar observasi siswa dan tes hasil belajar. Hasil penelitian menunjukkan bahwa penerapan model pembelajaran Snowball Throwing dapat meningkatkan aktivitasdan hasil belajar siswa kelas VII 4 SMPN 3 Kota Bengkulu.Peningkatan hasil belajar siswa dapat dilihat dari nilai rata-rata hasil belajar dari siklus 1 hingga siklus III. Pada siklus 1 rata-rata hasil belajar matematika siswa yaitu 74,57. Pada siklus II rata-rata hasil belajar siswa yaitu 75,14. Pada siklus III ratarata hasil belajar siswa yaitu 78,14. Maka penerapan model pembelajaran snowball throwing dapat meningkatkan hasil belajar siswa yang dilihat dari peningkatan rata-rata dari siklus 1 hingga siklus III, yaitu 74,$57 ; 75,14 ; 78,14$.
\end{abstract}

Kata Kunci: model snowball throwing, aktivitas belajar, hasil belajar

\begin{abstract}
This study aims to improve the activity and student learning outcomes by applying the learning model Snowball Throwing. The type of research conducted is Classroom Action Research (CAR) with data collection techniques through student observation sheets and test results learning. The results showed that the application of Snowball Throwing learning model can improve the activity and learning outcomes of students of class VII SMPN 34 Bengkulu City. Improved student learning outcomes can be seen from the average learning outcomes from cycle I to cycle III. On the 1st cycle average student learning outcomes of 74,57. In cycle II the average of student learning outcomes is 75.14. In cycle III the average of student learning result that is 78.14. Then the application of Learning Model Throwing Snowball can improve student learning outcomes as seen from an average increase of cycle I to cycle III, ie 74.57; 75, 14; 78.14.

Keywords: model snowball throwing, learning activities, learning outcomes
\end{abstract}

\section{PENDAHULUAN}

Berdasarkan pengalaman magang 3 di SMP Negeri 3 Kota Bengkulu diketahui bahwa proses pembelajaran disana dilakukan dengan metode ceramah dengan hanya memberikan materi pembelajaran yang hanya berfokus pada pemberian konsep-konsep, informasi, dan fakta sebanyak-banyaknya kepada siswa. Sehingga materi yang diajarkan kepada siswa sering menimbulkan salah persepsi atau susah dipahami oleh siswa, dan tidak relevan dengan karakter siswa sehingga pembelajaran tidak menarik bagi siswa.

Untuk mengatasi per-masalahan diatas diperlukan model pembelajaran yang membuat siswa lebih aktif. Salah satu cara untuk meningkatkan hasil belajar mate-matika siswa adalah dengan penerapan model snowball throwing. Suprijono (2014:128) menyatakan model pembelajaran snowball throwing melatih siswa untuk lebih tanggap menerima pesan dari kelompok lain dalam bentuk bola salju yang terbuat dari kertas dan menyampaikan pesan tersebut kepada temannya dalam satu kelompok. Penerapan model ini diharapkan dapat membangun motivasi siswa untuk mempelajari matematika. Model snowball throwing mengkondisikan siswa untuk lebih aktif dalam kegiatan belajar, siswa diajak memahami konsep pemahaman materi yang sulit serta untuk mengetahui sejauh mana 
pengetahuan dan kemampuan siswa dalam materi tersebut.

Berdasarkan latar belakang yang diuraikan di atas penulis mendapatkan ide untuk melakukan penelitian dengan judul "Penerapan Model Pembelajaran Snowball Throwing untuk Meningkatkan Hasil Belajar Siswa Kelas VII SMP Negeri 3 Kota Bengkulu Tahun Pelajaran 2016/2017 pada Pokok Bahasan Segitiga dan Segi Empat".

Model pembelajaran snowball throwing pertama kali dari game fisik dimana segumpalan salju dilempar dengan maksud memukul orang lain. Snowball throwing merupakan model pembelajaran dengan menggunakan bola, di dalam bola tersebut ada soal, soal tersebut dilemparkan kepada teman kelompok. Dapat diartikan sebagai model pembelajaran dengan menggunakan bola pertanyaan dari kertas yang digulung bulat berbentuk bola kemudian dilemparkan secara bergiliran dengan anggota kelompok lainnya (Tarida dan Usodo, 2015:907). Model pembelajaran snowball throwing merupakan pengem-bangan dari model pembelajaran diskusi dan merupakan bagian dari model pembelajaran kooperatif (Shoimin,2014:174). Hanya saja, pada model ini, kegiatan belajar diatur semenarik mungkin sehingga proses belajar mengajar di dalam kelas dapat berlangsung dengan lebih menyenangkan.

Menurut Shoimin (2014:175) langkahlangkah model pem-belajaran Snowball Throwing

\section{Fase 1 :}

Menyampaikan seluruh tujuan dalam pembelajaran dan memotivasi siswa.

\section{Fase 2 :}

Menyajikan informasi tentang materi pembelajaran siswa.

\section{Fase 3 :}

Memberikan informasi kepada siswa tentang prosedur pelaksanaan pembelajaran snowball throwing.

Membagi siswa ke dalam kelompok-kelompok belajar yang terdiri dari 6 orang siswa.

\section{Fase 4 :}

-Memanggil ketua kelompok dan menjelaskan materi.
- Meminta ketua kelompok kembali ke kelompok masing-masing untuk menjelaskan materi kepada temannya.

- Memberikan selembar kertas pada setiap kelompok dan meminta kelompok tersebut menulis pertanyaan sesuai dengan materi yang dijelaskan guru.

- Meminta setiap kelompok untuk menggulung dan melemparkan pertanyaan yang telah ditulis pada kertas kepada kelompok lain.

- Meminta setiap kelompok menuliskan jawaban atas pertanyaan yang didapatkan dari kelompok lain pada kertas kerja tersebut.

Fase 5 :Evaluasi.

Guru meminta setiap kelompok untuk membacakan jawaban atas pertanyaan yang diterima dari kelompok lain.

\section{Fase 6 :}

Memberikan penilaian terhadap hasil kerja kelompok

Menurut Sardiman (2011:103) prinsip dalam aktivitas belajar yang berorientasi pada pandangan ilmu jiwa lama yang berarti aktivitasdominan dilakukan oleh guru dan aktivitas belajar yang berorientasi pada pandangan ilmu jiwa modern yang berarti aktivitasdominan dilakukan oleh siswa. Sementara, menurut Sanjaya (2006: 132) aktivitas tidak hanya terbatas pada aktivitas fisik, melainkan meliputi aktivitas yang bersifat psikis seperti aktivitas mental. Dari kedua pendapat tersebut dapat diartikan bahwa aktivitas yang timbul dari siswa akan mengakibatkan pula terbentuknya pengetahuan dan keterampilan yang akan mengarah pada peningkatan prestasi siswa.

Aktivitas siswa merupakan kegiatan atau perilaku yang terjadi selama proses belajar mengajar. Kegiatan yang dimaksud adalah kegiatan yang mengarah pada proses belajar seperti bertanya, berdiskusi, mengajukan pendapat, mengerjakan tugas-tugas, dapat menjawab pertanyaan dari guru dan bisa bekerja sama dengan siswa yang lain dan 
mampu menyelesaikan masalah yang sudah diajarkan.

Dalam mengajar, guru harus sudah mengetahui tujuan pembelajaran yang harus dicapai. Menurut M. Thobroni (2009: 20), hasil belajar dibedakan dalam lima aspek, yaitu:

1) Informasi verbal, yaitu kapabilitas mengungkapkan pengetahuan dalam bentuk bahasa, baik lisan maupun tertulis. Kemampuan merespon secara spesifik terhadap rangsangan spesifik. Kemampuan tersebut tidak memerlukan manipulasi simbol, pemecahan masalah, maupun penerapan aturan.

2) Keterampilan intelektual, yaitu kemampuan mempresentasikan konsep dan lambang. Keterampilan intelektual terdiri dari kemampuan meng-kategorisasi,kemampuan analitis-sintetis fakta-konsep, dan mengembangkan prinsip-prinsip keilmuan.Keterampilan intelektualmerupakan kemampuan melakukan aktivitas kognitif bersifat khas.

3) Strategi kognitif, yaitu kecakapan menyalurkan dan mengarahkan aktivitas kognitifnya. Kemampuan ini meliputi penggunaan konsep dan kaidah dalam memecahkan masalah.

4) Keterampilan motorik, yaitu kemampuan melakukan serangkaian gerak jasmani dalam urusan dan koordinasi sehingga terwujud otomatisme gerak jasmani.

5) Sikap adalah kemampuan menerima atau menolak objek berdasarkan penilaian terhadap objek tersebut, sikap berupa kemampuan menginternalisasi dan eksternalisasi nilai-nilai. Sikap merupakan kemampuan menjadikan nilai-nilai sebagai standar perilaku.

Adapun rumusan masalah dalam penelitian ini adalah :

1. Bagaimana Penerapan Model pembelajaran Snowball Throwing dapat meningkatkan Aktivitas belajar siswa pokok bahasan segitiga dan segi empat dikelas VII SMP Negeri 3 Kota Bengkulu ?

2. Bagaimana Penerapan Model pembelajaran Snowball Throwing dapat meningkatkan Hasil belajar siswa pada pokok bahasan segitiga dan segi empat di kelas VII SMP Negeri 3 Kota Bengkulu ?

Adapun tujuan yang hendak dicapai dalam penelitian ini adalah:

1. Untuk mengetahui cara meningkatkan aktivitas belajar matematika siswa melalui penerapan model pembelajaran snowball throwing?

2. Untuk mengetahui cara meningkatkan hasil belajar matematika siswa melalui penerapan model pembelajaran snowball throwing?

\section{METODE PENELITIAN}

Jenis penelitian yang dilakukan adalah penelitian tindakan kelas (PTK). Penelitian tindakan kelas berasal dari istilah bahasa inggris Classroom Action Research, yaitu penelitian yang dilakukan pada sebuah kelas untuk mengetahui akibat tindakan yang diterapkan pada suatu subyek penelitian di kelas tersebut, (Trianto, 2010:13).PTK merupakan suatu tindakan atau aktivitas yang berbentuk siklus dan sengaja dilakukan dengan tujuan untuk memecahkan masalah-masalah yang ada dalam pembelajaran.

Penelitian yang dilakukan adalah Penelitian Tindakan Kelas (PTK) yang dilaksanakan Beberapa siklus dilaksanakan 20 April 2017 sampai 27 Mei 2017. Dalam setiap siklus terdiri dari beberapa pertemuan, Setiap siklus meliputi empat tahapan, yaitu perencanaan (planning), pelaksanaan (acting), pengamatan (observing) dan refleksi (reflecting).

Nilai rata-rata hasil belajar setiap siswa diperoleh dari nilai tes setiap siklus. Adapun nilai rata-rata hasil belajar siswa dihitung sebagai berikut: $\bar{x}=\frac{\sum X}{N}$

Keterangan:

$\bar{x} \quad$ : Nilai rata-rata

$\sum \mathrm{x}$ : Jumlah nilai-nilai akhir siswa

$\mathrm{N}$ : Banyaknya skor-skor itu sendiri

(Sudijono, 2009: 67)

Berdasarkan kurikulum 2013 di SMP Negeri 3 Kota Bengkulu menyatakan ketuntasan belajar untuk (a) individu: jika siswa mendapat nilai $\geq 74$, (b) klasikal: jikaket $80 \%$ siswa mendapat nilai $\geq 74$. Presentase 
ketuntasan belajar (p) klasikal dihitung dengan menggunakan rumus:

$$
p=\frac{\sum \text { siswa yang tuntas belajar }}{\sum \text { seluruh siswa }} \times 100 \%
$$

(Aqib dkk , 2014: 41)

Indikator keberhasilan dalam penelitian ini adalah: Aktivitas siswa dikatakan aktif jika kriteria penilaian berada pada kriteria baik pada lembar observasi aktivitas siswa memenuhi interval $24<x<30$, dan Hasil belajar dikatakan tuntas jika siswa mendapatkan nilai $\geq$ 74. Sedangkan ketuntasan belajar klasikal di SMP Negeri 3 Kota Bengkulutercapai apabila tuntas apabila $\geq 80 \%$ siswa tuntas belajar.

\section{HASIL DAN PEMBAHASAN}

Tabel 4.2 Hasil Observasi Aktivitas Siklus I

\begin{tabular}{|c|c|c|c|c|}
\hline Rertemuan & $\begin{array}{l}\text { Pertem } \\
\text { uan 1 }\end{array}$ & $\begin{array}{c}\text { Pertem } \\
\text { uan } 2\end{array}$ & $\begin{array}{c}\text { Pertemu } \\
\text { an 3 }\end{array}$ & $\begin{array}{c}\text { Rata- } \\
\text { Rata }\end{array}$ \\
\hline Pengamatat 1 & 17 & 18 & 19 & $\mathbf{1 8}$ \\
\hline Pengamat 2 & 17 & 18 & 20 & $\mathbf{1 8 , 3 3}$ \\
\hline Rata-Rata & $\mathbf{1 7}$ & $\mathbf{1 8}$ & $\mathbf{1 9 , 5}$ & $\mathbf{1 8 , 1 6}$ \\
\hline Kriteria & $\begin{array}{c}\text { Cukup } \\
\text { Aktif }\end{array}$ & $\begin{array}{c}\text { Cukup } \\
\text { Aktif }\end{array}$ & $\begin{array}{c}\text { Cukup } \\
\text { Aktif }\end{array}$ & $\begin{array}{c}\text { Cukup } \\
\text { Aktif }\end{array}$ \\
\hline
\end{tabular}

\subsection{Hasil Belajar Siswa Siklus I}

\begin{tabular}{|c|c|}
\hline Keterangan & $\begin{array}{c}\text { Nilai Akhir Tes } \\
\text { Akhir Siklus I }\end{array}$ \\
\hline Nilai Tertinggi & 95 \\
\hline Nilai Terendah & 50 \\
\hline Nilai Rata-Rata & 74,57 \\
\hline $\begin{array}{c}\text { Persentase Ketuntasan } \\
\text { Belajar }\end{array}$ & $57,14 \%$ \\
\hline Indikator Keberhasilan & Belum Berhasil \\
\hline
\end{tabular}

Tabel 4.5 Hasil Observasi Aktivitas siklus II

\begin{tabular}{|c|c|c|c|c|}
\hline $\begin{array}{c}\text { Rertemuan } \\
\text { Pengangt }\end{array}$ & $\begin{array}{c}\text { Pertem } \\
\text { uan 1 }\end{array}$ & $\begin{array}{c}\text { Pertemua } \\
\text { n 2 }\end{array}$ & $\begin{array}{c}\text { Pertem } \\
\text { uan 3 }\end{array}$ & $\begin{array}{c}\text { Rata- } \\
\text { Rata }\end{array}$ \\
\hline $\begin{array}{c}\text { Pengamat } \\
1\end{array}$ & 20 & 22 & 23 & $\mathbf{2 1 , 6 6}$ \\
\hline $\begin{array}{c}\text { Pengamat } \\
2\end{array}$ & 21 & 23 & 24 & $\mathbf{2 2 , 6 6}$ \\
\hline Rata-Rata & $\mathbf{2 0 , 5}$ & $\mathbf{2 2 , 5}$ & $\mathbf{2 3 , 5}$ & $\mathbf{2 2 , 1 6}$ \\
\hline Kriteria & $\begin{array}{c}\text { Cukup } \\
\text { Aktif }\end{array}$ & $\begin{array}{c}\text { Cukup } \\
\text { Aktif }\end{array}$ & $\begin{array}{c}\text { Cuku } \\
\text { pktif } \\
\text { Aktif }\end{array}$ & $\begin{array}{c}\text { Cukup } \\
\text { Aktif }\end{array}$ \\
\hline
\end{tabular}

Tabel 4.6 Hasil Belajar Siswa Siklus II

\begin{tabular}{|c|c|}
\hline Keterangan & $\begin{array}{c}\text { Nilai Akhir Tes Akhir } \\
\text { Siklus II }\end{array}$ \\
\hline Nilai Tertinggi & 95 \\
\hline Nilai Terendah & 50 \\
\hline Nilai Rata-Rata & 75,14 \\
\hline $\begin{array}{c}\text { Persentase Ketuntasan } \\
\text { Belajar }\end{array}$ & $74,28 \%$ \\
\hline Indikator Keberhasilan & Belum Berhasil \\
\hline
\end{tabular}

Tabel 4.8 Hasil Observasi Aktivitas Siklus III

\begin{tabular}{|c|c|c|c|c|}
\hline $\begin{array}{l}\text { Rertemuan } \\
\text { Pengamak }\end{array}$ & $\begin{array}{l}\text { Perte } \\
\text { muan } \\
1\end{array}$ & $\begin{array}{c}\text { Pertemu } \\
\text { an 2 }\end{array}$ & $\begin{array}{c}\text { Perte } \\
\text { mua } \\
\text { n 3 }\end{array}$ & $\begin{array}{c}\text { Rata- } \\
\text { Rata }\end{array}$ \\
\hline Pengamat 1 & 24 & 26 & 28 & $\mathbf{2 6}$ \\
\hline Pengamat 2 & 25 & 27 & 28 & $\mathbf{2 6 , 6 6}$ \\
\hline Rata-Rata & $\mathbf{2 4 , 5}$ & $\mathbf{2 6 , 5}$ & $\mathbf{2 8}$ & $\mathbf{2 6 , 3 3}$ \\
\hline Kriteria & Aktif & Aktif & $\begin{array}{c}\text { Akti } \\
\text { f }\end{array}$ & $\begin{array}{c}\text { Cukup } \\
\text { Aktif }\end{array}$ \\
\hline
\end{tabular}

Tabel 4.9 Hasil belajar siswa siklus III

\begin{tabular}{|c|c|}
\hline Keterangan & $\begin{array}{c}\text { Nilai Akhir Tes Akhir } \\
\text { Siklus III }\end{array}$ \\
\hline Nilai Tertinggi & 95 \\
\hline Nilai Terendah & 55 \\
\hline Nilai Rata-Rata & 78,14 \\
\hline $\begin{array}{c}\text { Persentase Ketuntasan } \\
\text { Belajar }\end{array}$ & $85,71 \%$ \\
\hline Indikator Keberhasilan & Berhasil \\
\hline
\end{tabular}

Tabel 4.10 Rekapan Hasil ObservasiAktivitas Siswa Setiap Siklus

\begin{tabular}{|c|c|c|}
\hline Siklus & $\begin{array}{c}\text { Skor rata-rata } \\
\text { Keseluruhan }\end{array}$ & Kriteria \\
\hline I & 18,16 & Cukup aktif \\
\hline II & 22,16 & Cukup aktif \\
\hline III & 26,33 & Aktif \\
\hline
\end{tabular}

Berdasarkan Tabel 4.10, terlihat bahwa hasil aktivitas siswa dari siklus I, II, III selalu meningkat.

Tabel 4.11Rekapan Hasil Belajar Siswa Setiap Siklus

\begin{tabular}{|l|c|c|c|c|c|}
\hline No & $\begin{array}{c}\text { Sikl } \\
\text { us } \\
\text { ke }\end{array}$ & $\begin{array}{c}\text { SkorTer } \\
\text { edah }\end{array}$ & $\begin{array}{c}\text { Skor } \\
\text { Tertin } \\
\text { ggi }\end{array}$ & $\begin{array}{c}\text { Nilai } \\
\text { Rata- } \\
\text { rata } \\
\text { Kelas }\end{array}$ & $\begin{array}{c}\text { Ketuntasan } \\
\text { Klasikal }\end{array}$ \\
\hline 1 & I & 50 & 95 & 74,57 & $57,14 \%$ \\
\hline 2 & II & 50 & 95 & 75,14 & $74,28 \%$ \\
\hline 3 & III & 55 & 95 & 78,14 & $85,71 \%$ \\
\hline
\end{tabular}


Berdasarkan Tabel 4.5 terlihat bahwa hasil belajar siswa dari siklus I, II, III selalu meningkat baik nilai rata - rata kelas ataupun ketuntasanklasikalnya.

\section{PEMBAHASAN}

Pada siklus I siswa sama sekali belum biasa membuat soal danmemotivasi dirinya sendiri untuk menggaliinformasi sendiri guna mendapatkan sebuah konsepuntuk membuat pertanyaan disebabkan karena selama ini siswa belum terbiasamenggaliinformasi dari berbagai sumber belajar. Hal ini terlihat jelas pada saat siswa membuat maupun menjawab soal tentang definisi dari bangun datar masih sangat kurang.

Pada siklus II aktivitas siswa mengalami peningkatan dimana aktivitas siswa pada siklus II secara umum sudah ada peningkatan dari siklus I. Hal ini menunjukkan bahwa penerapan model pembelajaransnowball throwing pada siklusII sudah dapat meningkatkan aktivitas belajar siswa.

Berdasarkan rekapanskoraktivitas siswa dapat dilihat bahwa aktivitas siswa yang masih berada pada kriteria kurang pada siklus I mengalami peningkatan, sehingga pada siklus II aktivitas tersebut sudah berada pada kriteria cukup bahkan ada yang mencapai kriteriaaktif. Hal ini memberikan gambaran bahwa siswa mulai terbiasa menggali informasi sendiri guna untuk membuat soal maupun menjawab soal. Selain itu, pada saat melakukan aktivitas diskusi kelompok interaksi siswa pun terlihat lebih baik dibandingkan siklus I. Hal ini terlihat dari adanya kemauan dari siswa yang berkemampuan tinggi untuk mengarahkan dan membimbing anggota kelompok lainnya, Hal ini tentunya memberikan dampak positif bagi siswa-siswa yang berkemampuan sedang dan rendah untuk lebih aktif dalam diskusi kelompok.

Hasil belajar siswa pada penelitian ini ditentukan ber-dasarkan hasil tes yang diperoleh siswa setiap siklus. Berdasarkan hasil penelitian diperoleh nilai rata-rata siswa pada siklus I sebesar 74,57 dengan nilai terendah 50 dan nilai tertinggi 95. Pada siklus II nilai ratarata siswa sebesar 75,14 dengan nilai terendah 50 dan nilai tertinggi 95 , sedangkan pada siklus III nilai rata-rata siswa sebesar 78,14 dengan nilai terendah 55 dan nilai tertinggi 95 . Hal ini dikarenakan pada siklus III syarat ketuntasan yang ingin dicapai telah terpenuhi. Jadi siklus pembelajaran terhenti pada siklus III.

Pada siklus I nilai rata-rata siswa masih rendah dengan ketuntasan belajar klasikal sebesar 57,14\%. Maka ini menunjukkan bahwa 20 dari 35 siswa yang hadir pada saat tes memperoleh nilai $\geq 75$.

Pada siklus II secara keseluruhan hasil belajar siswa mengalami peningkatan dimana nilai rata-rata siswa sebesar 75,14 dengan ketuntasan belajar klasikal sebesar 74,28\%. Hasil tersebut menunjukkan bahwa terdapat 26 siswa yang tuntas dari 35 siswa yang hadir pada saat tes dan masih ada sembilan orang siswa yang belum tuntas.

Pada siklus III nilai rata-rata siswa mengalami peningkatan yang cukup signifikan dibandingkan siklus sebelumnya, dimana nilai rata-rata siswa pada siklus ini sebesar 78,14 dengan ketuntasan belajar klasikal sebesar $85,71 \%$. Hasil tersebut telah memenuhi indikator keberhasilan dan sekaligus menunjukkan bahwa penerapan model pembelajaransnowball throwing berhasil meningkatkan hasil belajar siswa, Adapun keberhasilan tersebut disebabkan oleh beberapa faktor diantaranya bertambahnya minat siswa untuk melakukan kegiatan pembelajaran. Hal tersebut bermakna bahwa penerapan modelsnowball throwing dengan menggunakan bola kecil dan lembar materidisiapkan guru berhasil memotivasisiswa untuk belajar sehingga siswa dapat memperoleh dan memahami sebuah konsep yaitu sifat-sifat bangun datar segitiga dan segiempat.

\section{PENUTUP}

\section{Kesimpulan}

Dari hasil penelitian dan pembahasan disimpulkan bahwa:

1. Penerapan model pembelajaran snowball throwing dalam pembelajaran matematika di kelas VII 4 SMP Negeri 3 Kota Bengkulu dapat meningkatkan aktivitas siswa yaitu dengan cara : 1) mengelompokkan siswa ke dalam kelompok belajar yang beranggotakan 5 sampai 6 orang, 2) mendorong siswa untuk 
aktif dalam kegiatan presentasi guna membiasakan siswa untuk saling bertukar pendapat untuk menyelesaikan permasalahan yang terdapat pada soal, 3) dalam pembelajaran dengan memberikan bimbingan serta mendorong siswa untuk aktif dalam kegiatan presentasi guna membiasakan siswa untuk saling bertukar pendapat. Peningkatan aktivitas siswa dapat dilihat dari hasil observasiaktivitas siswa siklus I, siklus II, dan siklus III secara berturut-turut adalah 18,16 (kriteria cukup aktif) , 22,16 (kriteria cukupaktif), dan 26,33 (kriteriaaktif).

2. Penerapan model pembelajaransnowball throwingdapat me-ningkatkan hasil belajar mate-matika siswa di kelas VII 4 SMP Negeri 3 Kota Bengkulu terutama dalam kegiatan diskusi untuk menjawab soal. Hal ini terlihat dari nilai rata-rata hasil belajar siswa pada setiap siklus yang mengalami peningkatan. Nilai rata-rata siswa pada siklus I adalah 74,57 pada siklus II adalah 75,14 dan pada siklus III adalah 78,14. Ketuntasan belajar klasikalsiswa mengalami peningkatan setiap siklus dari $57,14 \%$ pada siklus I menjadi $74,28 \%$ pada siklus II dan terus meningkat menjadi $85,71 \%$ pada siklus III.

\section{Saran}

Dari hasil penelitian dalam penerapan model pembelajaran Snowball Throwing dalam kegiatan pembelajaran matematika peneliti menyarankan:

1. Dalam melaksanakan proses pembelajaran matematika dengan penerapan model pembelajaran snowball throwing guru mata pelajaran harus lebih aktif dalam melakukan pem-belajaran, lebih mem-perhatikan siswa yang cenderung malu dan pendiam, agar siswa tidak merasa kesulitan sehingga hasil belajarnya meningkat.

2. Guru mata pelajaran matematika dalam menerapkan model pembelajaran snowball throwing dalam proses pembelajaran hendaknya memilih materi yang tidak terlalu sulit yang cocok dengan model tersebut, karena tidak semua materi dapat dipelajari dengan menggunakan model pembelajaran ini.

3. Guru menyajikan masalah yang sederhana, tetapi siswa merasa tertantang untuk menyelesaikannya dan masalah tersebut tidak hanya dapat dipecahkan oleh siswa dengan kemampuan tinggi saja, tetapi juga dapat dipecahkan oleh siswa dengan kemampuan sedang dan rendah.

\section{DAFTAR PUSTAKA}

Aqib. 2014. Model-Model, Media, dan Strategi Pembelajaran Kontekstual (Inovatif). Bandung: Yerama widia.

Shoimin Aris. 2014. 68 Model Pembelajaran Inovatif dalam Kurikulum 2013. Yogyakarta: Ar Ruzz Media.

Suprijono, Agus. 2014. Kooperative Learning. Yogyakarta: pustaka pelajar.

hobroni,M. 2009. Belajar dan Pembelajaran. Yogyakarta: Ar Ruzz Media.

Trianto. 2010. Panduan Lengkap Penelitian Tindakan Kelas. Jakarta: Prestasi Pustakaraya.

Usodo dan Tarida. Problematika Penerapan Model Pembelajaran Snowball Throwing dan Alternatif Penyelesaian Pada Pembelajaran Matematika.Seminar Nasional Matematika dan Pendidikan Matematika UNY (2015).

Sanjaya, Wina. 2006. Strategi Pembelajaran. Jakarta: Prenada Media Group

Sardiman. 2011. Interaksi dan Motivasi Belajar Mengajar . Jakarta: PT Raja Grafindo Persada. 